Journal of Applied Biology \& Biotechnology Vol. 5 (02), pp. 077-084, March-April, 2017

Available online at http://www.jabonline.in

DOI: $10.7324 / \mathrm{JABB} .2017 .50212$

(c) $\mathrm{BY}-\mathrm{NC}-\mathrm{SA}$

\title{
Knock down efficacy of commercially available insecticides against Anopheles gambiae
}

\author{
Nicholas K. Makworo, ${ }^{1,}$, Vincent O. Ochieng ${ }^{2}$, Dorington O. Ogoyi ${ }^{3}$, Richard W. Mukabana ${ }^{1}$ \\ ${ }^{1}$ University of Nairobi, School of Biological Sciences, P.O Box 30197-00100 Nairobi, Kenya. ${ }^{2}$ University of Nairobi Department of Biochemistry, P.O \\ Box 30197-00100 Nairobi, Kenya. ${ }^{3}$ Department of Biochemistry and Biotechnology, Technical University of Kenya, P.O Box 52428, 00200 Nairobi, \\ Kenya. ${ }^{4}$ Vector-Borne and Neglected Tropical Disease Control Unit, Ministry of Health- Migori County, P.O Box202-40400 Suna Migori, Kenya.
}

\begin{tabular}{|c|c|}
\hline ARTICLE INFO & ABSTRACT \\
\hline $\begin{array}{l}\text { Article history: } \\
\text { Received on: } 14 / 11 / 2016 \\
\text { Accepted on: } 30 / 12 / 2016 \\
\text { Available online: } 20 / 03 / 2017\end{array}$ & $\begin{array}{l}\text { Knockdown efficacy of commercial aerosol insecticides against laboratory reared Anopheles gambiae } \\
\text { Kisumu strain mosquitoes and suppression of indoor resting density of A. gambiae complex mosquitoes in the } \\
\text { field were investigated in the study. Laboratory reared } 2-5 \text { days old female A. gambiae mosquitoes were } \\
\text { released into Peet-Grady chambers, sprayed with } 0.3 \pm 0.1 \mathrm{~g} \text { of insecticides. Knock down rates were observed }\end{array}$ \\
\hline $\begin{array}{l}\text { Key words: } \\
\text { Anopheles gambiae, } \\
\text { Knock down time, } \\
\text { Mortality rate, } \\
\text { Indoor resting density. }\end{array}$ & $\begin{array}{l}\text { for one hour and mortality rates after } 24 \mathrm{hrs} \text { of spraying. Field efficacy studies were carried out by spraying } \\
\text { houses with near uniform indoor resting densities of A. gambiae complex mosquitoes with aerosol } \\
\text { insecticides and mosquitoes collected. Morphological and molecular characterization of mosquitoes was } \\
\text { done. Probit analysis on knock down rates was carried out. Mortality rates and Mean indoor resting densities } \\
\text { were compared using ANOVA in SPSS version } 16 \text {. The } \mathrm{KT}_{50} \text { and } \mathrm{KT}_{95} \text { of Kenyan Baygon }{ }^{\circledR} \text { and Kenyan raid }{ }^{\circledR} \\
\text { differed significantly with the other insecticides. Nigerian Baygon }{ }^{\circledR} \text { achieved the lowest mortality rate of } 87 \% \\
\text { and differed significantly }(\mathrm{P}<0.05) \text { with other insecticides. No significant differences in suppression of indoor } \\
\text { resting densities of A. gambiae complex mosquitoes was observed }(\mathrm{p}>0.05) \text {. Collected A. gambiae complex } \\
\text { mosquitoes corresponded to A. arabiensis. The low knock down values by Kenyan Baygon }{ }^{\circledR} \text {, Kenyan raid }{ }^{\circledR} \\
\text { and the low mortality rate by Nigerian Baygon }{ }^{\circledR} \text { can be attributed to reduced efficacy rather than development } \\
\text { of resistance. Whether the low deterrence of Anopheles gambiae complex mosquitoes into houses is due to } \\
\text { development of pyrethroid insecticide resistance can be authenticated in another study. }\end{array}$ \\
\hline
\end{tabular}

\section{INTRODUCTION}

Notwithstanding the control efforts, malaria remains one of the greatest health burdens to the public especially to the SubSaharan Africa [1]. In 2010, there were 219 million episodes of malaria with approximately 660,000 deaths according to the World Malaria Report [1]. Ninety per cent of the deaths were from Africa; $16 \%$ of them being children under the age of five years. Malaria in tropical and sub-tropical areas is due to temperatures favouring the development of Plasmodium parasites in Anopheles mosquito vectors [2]. Increases in malaria-specific mortality has been attributed to development of drug resistance

* Corresponding Author

Email: nicholaskibegwa@gmail.com by the parasites, spread of insecticide resistant mosquitoes, poverty, social and political upheavals, lack of an effective vaccine and climate change [3]. Mosquitoes are vectors of many diseases within and outside the tropics such as malaria, filariases, numerous viral diseases such as dengue, Japanese encephalitis and yellow fever and allergic reactions to proteins injected by mosquito bites $[4,5,6]$. Mosquitoes also act as nuisance pests due to their biting behaviour. Any mosquito control strategy should encompass the control of mosquitoes as vectors and nuisance pests. The major malaria vectors in Kenya are Anopheles gambiae complex mosquitoes. They are involved in transmission of other vectorborne diseases. Anopheles gambiae complex mosquitoes previously consisted of seven sibling species [7]. Two more sibling species have been discovered in the recent past [8]. A. gambiae and $A$. arabiensis mosquitoes are highly efficient in transmitting malaria parasites in Africa $[9,10]$. 
Malaria and other vector-borne disease control strategies include the use of pyrethroid insecticides. Pyrethoids are consituted as combinations of different isomers in varying proportions. Pyrethroids are used mostly in Indoor Residual Sprays (IRS) and in Long Lasting Insecticide Treated Nets (LLINs). Indeed IRS and LLINs have been suggested as the primary tools for malaria vector control and most of the efficacy studies have focused on the same [11]. Pyrethroids are also constituted as commercial aerosols which act by their knock down effect on mosquitoes [12].

They are meant for personal protection against mosquito bites and thus protection against mosquto-borne diseases. The emergence and spread of insecticide resistance to major classes of insecticides in some areas is threatening the success of vectorborne disease control programs[13,14,15,16]. Several efficacy studies on pyrethroid insecticides used in impregnation of bed nets and curtains have been carried out. While most of the studies have focused on insecticide treated nets, little has been carried out on insecticides constituted as aerosol pyrethroids, and where such exist; little has been carried out in Kenya.

Thus there is need to investigate the efficacy of aerosol commercial insecticides. This study reports laboratory knock down and mortality rates of $A$. gambiae mosquitoes by aerosol inseciticides. It also reports the suppression of indoor resting densities of An. gambiae complex mosquitoes in houses at Kigoche village in Ahero, Kisumu County part of Kenya after spraying with Insecticides.

\section{MATERIALS AND METHODS}

\subsection{Study design}

Controlled laboratory study was conducted at the University of Nairobi, Chiromo campus, School of Biological Sciences. It involved rearing of mosquitoes from egg to the adult stages. Then knock down efficacies of the insecticides were tested on adult Anopheles gambiae mosquitoes. Field study was carried out at Kigoche village in Ahero, Kisumu County Western part of Kenya where suppression of indoor resting densities of mosquitoes in village huts was evaluated. Anopheles gambiae complex mosquitoes collected from village huts were taken to Chiromo Centre for Biotechnology and Biotechnology for molecular based characterization.

\subsection{Aerosol insecticides Tested and active ingredients}

Aerosol insecticides for the study were obtained from Kenya, Nigeria and South Africa. Both laboratory and field efficacy studies were carried out. They were both tested in the laboratory and in the Field. The active ingredients constituting the insecticides were obtained from the manufacturer's labels and are as summarised in Table 1.

\subsection{Rearing of Anopheles gambiae mosquitoes}

Anopheles gambiae eggs were obtained from Thomas Odhiambo Campus (TOC) of the International Centre of Insect Physiology and Ecology (ICIPE). The insectary was divided into
Table 1: Active ingredients constituting the insecticides as obtained from the manufacturer label.

\begin{tabular}{|c|c|}
\hline Product & Active ingredients \\
\hline \multicolumn{2}{|c|}{ Active ingredients of Insecticides from Kenya } \\
\hline Mortein Doom Ultrafast $^{\circledR}$ & $\begin{array}{l}\text { D- Transallethrin } 0.125 \% \text {, Permethrin } \\
0.040 \% \text {, imiprothrin } 0.025 \%\end{array}$ \\
\hline Raid $^{\circledR}$ & $\begin{array}{l}\text { Imiprothrin } 0.05 \mathrm{~g} / \mathrm{kg} \text {, Cyfluthrin } \\
0.15 \mathrm{~g} / \mathrm{kg}\end{array}$ \\
\hline Baygon $^{\circledR}$ & $\begin{array}{l}\text { Imiprothrin } 0.050 \mathrm{~g} / \mathrm{kg} \text {, Cyfluthrin } \\
0.15 \mathrm{~g} / \mathrm{kg}\end{array}$ \\
\hline Ridsect $^{\circledR}$ & $\begin{array}{l}\text { Prallethrin- } 0.081 \% \mathrm{w} / \mathrm{w}, \text { Deltamethrin- } \\
0.019 \% \mathrm{w} / \mathrm{w}\end{array}$ \\
\hline \multicolumn{2}{|c|}{ Active ingredients of insecticides from Nigeria } \\
\hline Mortein Doom Ultrafast ${ }^{\circledR}$ & $\begin{array}{l}\text { D- Transallethrin } 0.125 \% \text {, Permethrin } \\
0.040 \% \text {, imiprothrin } 0.025 \%\end{array}$ \\
\hline Mobil $^{\circledR}$ & $\begin{array}{l}\text { Neo-Pynamin } 0.25 \% \text {, Prallethrin } \\
0.04 \% \text {,Cyphenothrin } 0.05 \%\end{array}$ \\
\hline $\operatorname{Raid}^{\circledR}$ & $\begin{array}{l}\text { D- allethrin } 0.250 \% \text {, Tetramethrin } \\
0.15 \% \text {, Deltamethrin } 0.015 \%\end{array}$ \\
\hline Baygon $^{\circledR}$ & $\begin{array}{l}\text { 0.05\% imiprothrin, } 0.05 \% \text { prallethrin, } \\
0.015 \% \text { Cyfluthrin }\end{array}$ \\
\hline \multicolumn{2}{|c|}{ Active ingredients of insecticides from South Africa } \\
\hline Mortein PowerGard odourless ${ }^{\circledR}$ & $\begin{array}{l}\text { D-Transallethrin } 2.4 \mathrm{~g} / \mathrm{kg} \\
\text { Bioresmethrin } 0.2 \mathrm{~g} / \mathrm{kg}\end{array}$ \\
\hline Mortein PowerGard - Ultra fast ${ }^{\circledR}$ & $\begin{array}{l}\text { D-Transallethrin } 1.0 \mathrm{~g} / \mathrm{kg} ; \text { Imiprothrin } \\
0.2 \mathrm{~g} / \mathrm{kg} \text {; d-phenothrin } 0.3 \mathrm{~g} / \mathrm{kg}\end{array}$ \\
\hline
\end{tabular}

two units; the rearing unit and the experimental unit where bioassays were carried out. An automated heater was supplied to maintain the temperatures at $27 \pm 2^{\circ} \mathrm{C}$ and wetting of the floor to keep relative humidity at approximately $80 \pm 5$. The lighting system was set to go on and off at $6.00 \mathrm{am}$ and $6.00 \mathrm{pm}$ respectively to simulate field conditions. To obtain eggs for colony maintenance adult female mosquitoes were fed on human blood. Other $A$. gambiae mosquitoes for bioassays were fed on $10 \%$ sugar solution soaked in velvex tissue paper in vials. Adult mosquitoes were supplied with water by soaking cotton towels in water and spreading them on top of the cages. Larvae were fed on Tetramin® baby fish food early in the morning and late in the evening. Larvae rearing was done on small rearing trays $(25 \times 20 \times 14 \mathrm{~cm})$ filled with fresh borehole water. The trays were topped up with fresh water every day to make up for the water lost due to evaporation. Pupae were collected early in the morning and late in the evening, placed in pupae holding cups and transferred into adult holding cages covered with netting material where they emerged into adults.

\subsection{Knockdown and Mortality effect}

The discharge rate of each insecticide was determined by weighing the container full of insecticide. Then the insecticide was sprayed into the air for around 0.3 to 1 seconds and the container weighed. The difference before and after spraying was noted. This was done until an average discharge rate of $0.3 \pm 0.1 \mathrm{~g}$ was obtained $[17,18]$. Knock down efficacy was carried out using the PeetGrady chamber method [19, 17, 12]. The Peet-Grady chambers were measuring $0.7 \mathrm{~m}$ by $0.7 \mathrm{~m}$ by $0.7 \mathrm{~m}$. A total of 25 laboratory reared non-blood fed female Anopheles gambiae mosquitoes, 2-5 days old were liberated into the Peet-Grady chambers and given 2 minutes to acclimatize. The mosquitoes were then sprayed with the insecticides and knock down rates observed every minute for 
up to ten minutes, then after every ten minutes up to 60 minutes. The mosquitoes were then transferred to holding cups, fed with $10 \%$ sucrose and water. Mortality rates were observed $24 \mathrm{hrs}$ after spraying. Test replicates of four were carried out.

\subsection{Control Experiment}

Before efficacy tests were carried out, Peet-Grady chambers were washed with a multipurpose detergent solution, then with ethanol-acetone solution in the ratio of 19:1. This was done to free the chambers of any chemical from previous experiment. A total of 25, 2-5 days old, laboratory reared nonblood fed female Anopheles gambiae mosquitoes were liberated into the Peet-Grady chambers, knock down values observed for every minute up to ten minutes thereafter every ten minutes up to sixty minutes. Mosquitoes were put in holding cups, provided with $10 \%$ sucrose and water. Mortality was observed 24hours postspraying.

\subsection{Field Study Area}

Field study was carried out at Kigoche village in Ahero $\left(00^{\circ} 08^{1} \mathrm{~S}, 034^{\circ} 55^{1} \mathrm{E}\right)$, Kisumu County, Western Kenya. The village lies at an altitude of $1160 \mathrm{~m}$ above sea level with an average relative humidity of $65 \%$ and average annual rainfall of 1,000 $1,800 \mathrm{~mm}$. Ahero village is characterized with long rains from April to June and short rains from September to October.

\subsubsection{Indoor resting densities of A. gambiae complex mosquitoes before spraying the houses}

Twenty village huts with similar house characteristics were randomly picked: Mud-walled houses, roofed with corrugated iron sheet, no screens on doors/windows and no eaves between the walls and the roofs. In addition, no cooking was carried out in the houses. Mosquitoes were collected from the twenty houses using hand-held aspirators early in the morning from7.00am and not later than 9.30am, spending approximately ten minutes in each house to collect mosquitoes. The exercise was carried out for four days as from $30^{\text {th }}$ August to $1^{\text {st }}$ September 2011. Mosquitoes were put in holding cups and transferred to the laboratory at the Ahero Multi-purpose Development Training Institute (AMDTI) for morphological identification [7, 9]. Anopheles gambiae complex mosquitoes were preserved with silica gel in eppendorf tubes. The indoor resting densities of $A$. gambiae complex mosquitoes of each house were determined and eleven huts with uniform indoor resting densities of Anopheles gambiae complex mosquitoes were selected for the study.

\subsubsection{Suppression of indoor resting density of A. gambiae complex mosquitoes}

Ten houses were sprayed with the insecticides between 7.00am and 9.30am while the control house was not. Each of the ten houses was sprayed for about fifteen to twenty minutes. Windows and doors of the houses were shut and the owners advised not to open them until after ten to fifteen minutes. The owners were allowed to sleep in the huts after around twelve hours of spraying. Mosquitoes that entered the houses overnight were collected using hand-held aspirators [20]. Collected mosquitoes were then put in holding cups and transferred to the laboratory at Ahero Multi-purpose Development Training Institute (AMDTI) for morphological identification. A. gambiae complex mosquitoes were preserved in eppendorf tubes with silica gel and transferred to University of Nairobi, Centre for Biotechnology and Bioinformatics (CEBIB) for PCR-based molecular characterization. Aspiration of mosquitoes was done one day after spraying the houses with the insecticides. Six days were given for normalization of the indoor resting densities of Anopheles gambiae complex mosquitoes before a second spray was carried out. Four replicates were done for each treatment. To get rid of any residue effect of previous insecticide, the same insecticide was sprayed in the same house for the four replicates i.e. no rotation of insecticide treatment was done.

\subsubsection{DNA extraction}

DNA was extracted from mosquito legs, wings and in some cases the abdomen using the Collins' method with slight modifications [21, 22, 23]. The mosquito parts were cut and put into $1.5 \mathrm{ml}$ eppendorf tube using clean sterile forceps. Then $100 \mu \mathrm{l}$ of the grinding buffer consisting of $0.08 \mathrm{M} \mathrm{NaCl}, 0.16 \mathrm{M}$ Sucrose, $0.124 \mathrm{M}$ Trizma, $0.058 \mathrm{M}$ EDTA and $0.005 \mathrm{M}$ SDS was added. The samples were ground till there were no large fragments visible. Fourteen $(14 \mu \mathrm{l})$ of $8 \mathrm{M}$ potassium acetate was added and vortexed, transferred into crushed ice for 30 minutes and then centrifuged at 14000rpm for ten minutes. The supernatant was transferred into new sterile labelled $1.5 \mu \mathrm{l}$ eppendorf tubes and $200 \mu \mathrm{l}$ of $95 \%$ ethanol added and then kept at $4{ }^{\circ} \mathrm{C}$ overnight to allow for more ethanol precipitation. The samples were spun at 14000rpm for 20 minutes before ethanol was poured off leaving the DNA pellet intact. The DNA was washed with $200 \mu \mathrm{l}$ of $70 \%$ ethanol followed by $200 \mu \mathrm{l}$ of $95 \%$ ethanol. The tubes containing DNA were inverted in a velvex tissue paper to allow for drying. The pellet was re-suspended in 50 $\mu$ PCR water and briefly vortexed and allowed to stand at room temperature for 20 minutes before storage at $-20^{\circ} \mathrm{C}$

\subsubsection{Polymerase Chain Reaction:}

The PCR master mix reaction was prepared as earlier described $[24,25]$; On $12.5 \mu$ l sterile water, $2.5 \mu \mathrm{l} \mathrm{Taq} \mathrm{10X} \mathrm{PCR}$ buffer with $\mathrm{MgCl}_{2}$ was added, $2.5 \mu \mathrm{ldNTP}$ ( $2 \mathrm{mM}$ mix G, A, T ,C), $0.3 \mu \mathrm{l} \mathrm{MgCl}_{2}(25 \mathrm{mM}), 1.0 \mu \mathrm{l}$ of each of the following primers: $\mathrm{UN}(\mathrm{F}, 10 \mathrm{pmol} / \mathrm{ul})$ [ GTG TGC CCC TTC CTC GAT GT], AR(R, 10pmol/ul)[ AAG TGT CCT TCT CCA TCC TA], GA(R, 10pmol/ $\mu \mathrm{l})[$ CTG GTT TGG TCG GCA CGTTT], ME(R,

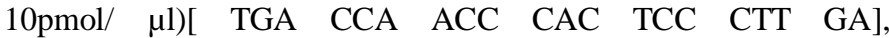
$\mathrm{QD}(\mathrm{R}, 10 \mathrm{pmol} / \mu \mathrm{l})[\mathrm{CAG}$ ACC AAG ATG GTT AGT AT], and $0.2 \mu \mathrm{l}$ Taq DNA polymerase ( $5 \mathrm{U} / \mu \mathrm{l}$ ) were added. Then $1 \mu \mathrm{l}$ of template DNA was added to make a $25 \mu \mathrm{l}$ PCR reaction mix. The PCR conditions were set as described by Scott et al, (1993) i.e. $94^{\circ}$ $\mathrm{C}$ for 5 minutes initial denaturation, 30 cycles of $\left(94^{\circ} \mathrm{C}\right.$ for 30 seconds for denaturation, annealing at $50^{\circ} \mathrm{C}$ for $30 \mathrm{sec}$, and 
extension at $72^{\circ} \mathrm{C}$ for $30 \mathrm{sec}$.), and a final extension at $72^{\circ} \mathrm{C}$ for 5 minutes for one cycle and held at $4^{\circ} \mathrm{C}$. The PCR products were electrophoresed through a $2 \%$ agarose gel containing ethidium bromide $(\mathrm{EtBr})$ then visualized by illumination through a short wave ultraviolet (UV) light.

\subsection{Data Analysis}

The percentage knock down values obtained were pooled together and subjected to probit analysis (SPSS software version 16). The $\mathrm{KT}_{50}$ and $\mathrm{KT}_{95}$ (time taken to knock down $50 \%$ and $95 \%$ of Anopheles gambiae mosquitoes respectively) values were obtained from probit analysis. The overlap or else of the $95 \%$ confidence intervals $(\mathrm{CI})$ of the $\mathrm{KT}_{50} \mathrm{~S}$ and $\mathrm{KT}_{95} \mathrm{~S}$ were used to determine the significant difference in knock down rates. Mean mortality rates were compared using the LSD (ANOVA post hoc test) test in SPSS and their statistical significance determined. The percentage rates were also compared to WHO standard values of resistance [26]. Data from the field was analysed by comparing the indoor resting densities of mosquitoes in houses using one way-ANOVA (SPSS version 16).

\section{RESULTS}

\subsection{Knock down values}

Knock down values $\left(\mathrm{KT}_{50} \mathrm{~S}\right.$ and $\mathrm{KT}_{95} \mathrm{~S}$ after probit analysis) of $A$. gambiae mosquitoes achieved by insecticides from Kenya with the respective $95 \%$ confidence intervals (CI) were as shown in Table 2. Ridsect ${ }^{\circledR}$ and Mortein doom ultrafast ${ }^{\circledR}$ were more effective (low $\mathrm{KT}_{50} \mathrm{~S}$ and $\mathrm{KT}_{95} \mathrm{~S}$ ) than $\mathrm{Raid}^{\circledR}$ and Baygon ${ }^{\circledR}$ (higher $\mathrm{KT}_{50} \mathrm{~S}$ and $\mathrm{KT}_{95} \mathrm{~S}$ ).

Table 2: Mean knock down rates of $A$. gambiae mosquitoes exposed to insecticides manufactured in Kenyan

\begin{tabular}{lll}
\hline \multicolumn{1}{c}{ Insecticide } & \multicolumn{1}{c}{$\mathbf{K T}_{\mathbf{5 0}}$} & \multicolumn{1}{c}{$\mathbf{K T}_{\mathbf{9 5}}$} \\
& \multicolumn{1}{c}{ Minutes (95 CI) } & \multicolumn{1}{c}{ Minutes (95 CI) } \\
\hline Mortein Doom Ultrafast $^{(B)}$ & $0.783(0.342-1.214)$ & $5.947(4.417-9.466)$ \\
Ridsect $^{(B)}$ & $0.412(0.078-0.821)$ & $4.339(3.011-7.335)$ \\
Raid $^{(B)}$ & $2.117(1.643-2.555)$ & $8.677(6.940-11.989)$ \\
Baygon $^{(B)}$ & $2.478(1.970-2.957)$ & $10.189(0.160-13.998)$ \\
\hline
\end{tabular}

The overlap of $95 \%$ confidence intervals (CI) of Ridsect ${ }^{\circledR}$ and Mortein doom ultrafast ${ }^{\circledR}$ in terms of $\mathrm{KT}_{50} \mathrm{~S}$ and $\mathrm{KT}_{95} \mathrm{~S}$ implies the knock down rates did not differ significantly with each other. But the knock down rates of Anopheles gambiae mosquitoes by these insecticides (Ridsect ${ }^{\circledR}$ and Mortein doom ultrafast ${ }^{\circledR}$ ) differed significantly with those of Raid $^{\circledR}$ and Baygon ${ }^{\circledR}$ with higher knock down times. The overlap of $95 \% \mathrm{CI}$ of $\mathrm{KT}_{50} \mathrm{~S}$ and $\mathrm{KT}_{95} \mathrm{~S}$ of Raid ${ }^{\circledR}$ and Baygon ${ }^{\circledR}$ implies there was no significant difference amongst themselves with respect to knocking down Anopheles gambiae mosquitoes.

Nigerian Baygon ${ }^{\circledR}$ achieved the lowest $\mathrm{KT}_{50}$, followed by Mobil $^{\circledR}$, Raid $^{\circledR}$ and Mortein PowerGard ${ }^{\circledR}$ in that order with respect to knocking down Anopheles gambiae mosquitoes (Table 3 after probit analysis). In terms of $\mathrm{KT}_{95}$, Baygon ${ }^{\circledR}$ achieved the lowest knock down time followed by Mortein PowerGard ${ }^{\circledR}$, Mobil $^{\circledR}$ and Raid ${ }^{\circledR}$. However the overlap of the $95 \%$ CI implies that the knock down value were not significantly different $(\mathrm{p}>0.05)$.

Table 3: Mean knock down rates of A. gambiae mosquitoes exposed to insecticides manufactured in Nigeria.

\begin{tabular}{lcc}
\hline \multicolumn{1}{c}{ Insecticide } & \multicolumn{1}{c}{$\mathbf{K T}_{\mathbf{5 0}}$} & \multicolumn{1}{c}{$\mathbf{K T}_{\mathbf{9 5}}$} \\
& Minutes (95 CI) & \multicolumn{1}{c}{ Minutes (95 CI) } \\
\hline Mortein PowerGard $^{\circledR}$ & $0.596(0.203-0.972)$ & $3.445(2.539-5.395)$ \\
Mobil $^{\circledR}$ & $0.551(0.167-0.945)$ & $3.877(2.818-6.182)$ \\
Raid $^{\circledR}$ & $0.571(0.180-0.972)$ & $4.181(3.049-6.689)$ \\
Baygon $^{\circledR}$ & $0.415(0.073-0.801)$ & $3.22(2.75-4.942)$ \\
\hline
\end{tabular}

The $\mathrm{KT}_{50} \mathrm{~S}$ and $\mathrm{KT}_{95} \mathrm{~S}$ (after probit analysis) against Anopheles gambiae mosquitoes and the respective $95 \%$ confidence intervals by the insecticides from South Africa were as shown in Table 4. Mortein PowerGard ultrafast insecticide was more effective as compared to Mortein PowerGard odorless but not significantly different $(\mathrm{p}>0.05)$.

Table 4: Mean knock down rates of A. gambiae mosquitoes exposed to insecticides manufactured in South Africa.

\begin{tabular}{|c|c|c|}
\hline Insecticide & $\begin{array}{c}\text { KT }_{50} \\
\text { Minutes (95 CI) }\end{array}$ & $\begin{array}{c}\text { KT }_{95} \\
\text { Minutes (95 CI) }\end{array}$ \\
\hline Mortein PowerGard Ultrafast $^{(B)}$ & $0.629(0.232-0.961)$ & $2.576(1.924-4.076)$ \\
\hline $\begin{array}{l}\text { Mortein } \\
\text { Odourless }\end{array}$ & $0.774(0.390-1.075)$ & $2.650(0.045-4.075)$ \\
\hline
\end{tabular}

\subsection{Mortality rates after $24 \mathrm{hrs}$ of spraying $A n$. gambiae s.s with insecticides}

The mortality rates of Anopheles gambiae mosquitoes achieved by the insecticides from Kenya, Nigeria and South Africa are as shown in figures 1,2 and 3 respectively. Most of the insecticides achieved high mortality rates (above 97\%) with the exception of Nigerian Baygon ${ }^{\circledR}$ which achieved a mortality rate of $87 \%$ and differed significantly $(\mathrm{p}<0.05)$ with the mortality rates achieved by other insecticides (ANOVA, SPSS version16; degrees of freedom (d.f) between groups was 9, d.f within groups was 30, $\mathrm{F}$ value $=4.558$ and $\mathrm{p}$ value was 0.001 ). According to WHO recommendations on susceptibility tests [26], the mortality rates achieved by the aerosol insecticides are within the acceptable range with the exception of Nigerian Baygon ${ }^{\circledR}$.

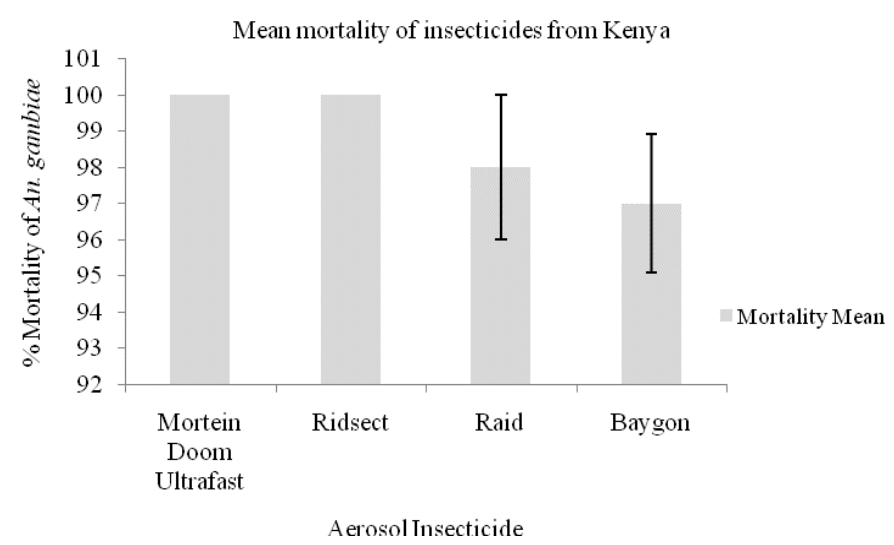

Fig. 1: Mean mortality rates of A. gambiae complex mosquitoes exposed to aerosol insecticides manufactured in Kenya. 


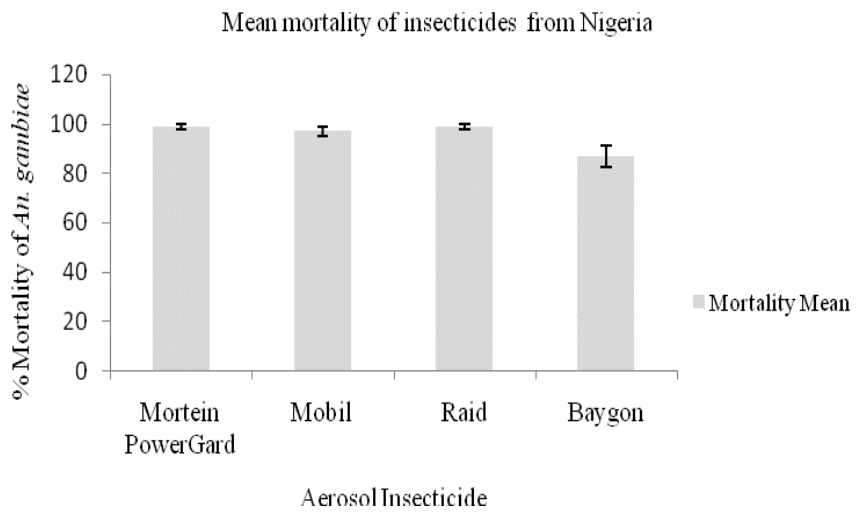

Fig. 2: Mean mortality rates of A. gambiae complex mosquitoes exposed to aerosol insecticides manufactured in Nigeria.

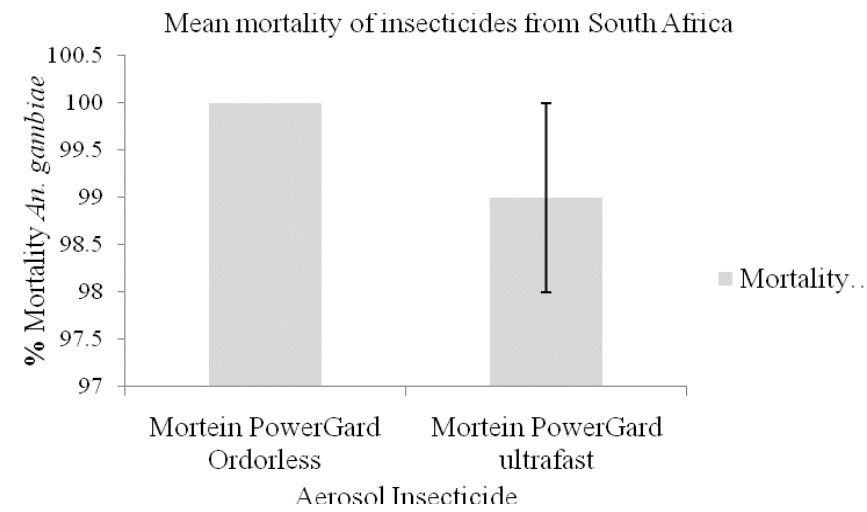

Fig. 3: Mean mortality rates of A. gambiae complex mosquitoes exposed to aerosol insecticides manufactured in South Africa.

\subsection{Field efficacy study}

After spraying the houses with the insecticides, Nigerian Mobil $^{\circledR}$ was the leading in deterrence and suppression of $A$. gambiae complex mosquitoes into houses with a mean indoor resting density of 3.75 .

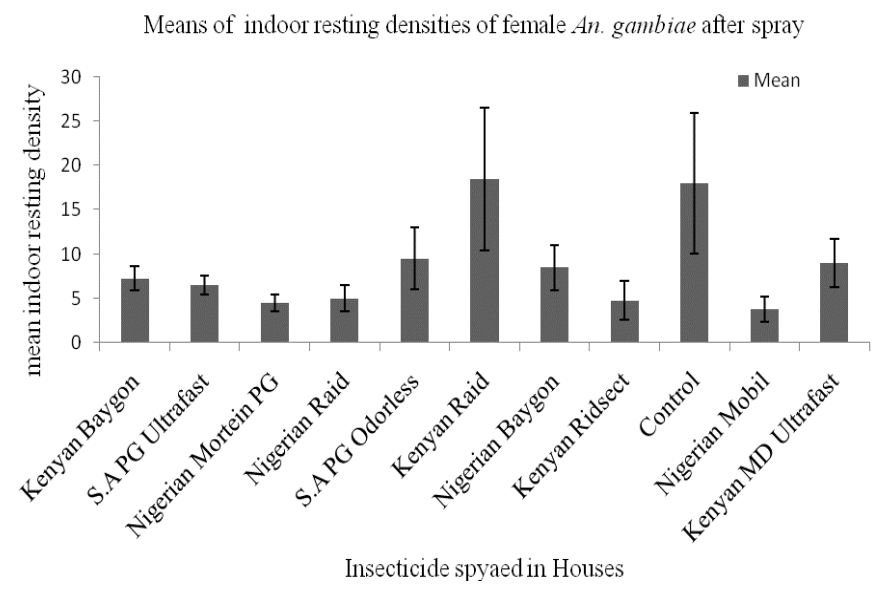

Fig. 4: Means of female A. gambiae complex mosquitoes collected after spraying houses. Key: S.A PG ultrafast- South African PowerGard Ultrafast $^{(\mathbb{B})}$ S.A PG odorless- South African PowerGard odorless' Kenyan MD ultrafast- Kenyan Mortein doom ultrafast ${ }^{\circledR}$, Nigerian Mortein PG- Nigerian Mortein PowerGard ${ }^{\circledR}$
This was followed by Nigerian Mortein PowerGard ${ }^{\circledR}$ with a mean of 4.5 and Kenyan Ridsect ${ }^{\circledR}$ with a mean indoor resting density of 4.75 . Kenyan Raid $^{\circledR}$ achieved the least suppression/deterrence of A. gambiae mosquitoes into houses with a mean indoor resting density of 18.5 exceeding that of the control house (Fig 4). However, when the mean indoor resting densities were compared using ANOVA there were no significant difference between them (d.f between groups 10, d.f within groups was 33, and $F$ value was 1.729 and the $p$ value 0.115 ).

\subsection{Molecular characterization of Anopheles gambiae complex mosquitoes}

A total of 381 A. gambiae complex mosquitoes were collected from the houses after spraying with the insecticides. DNA was extracted from 107 mosquitoes. After amplification by Polymerase Chain Reaction (PCR) and subjecting the PCR products through $2 \%$ agarose gel electrophoresis, the products were visualized through UV light. Seventy one out of one hundred and seven (71/107) samples (66.4\%) were positive for Anopheles arabiensis mosquitoes. Thirty samples failed to amplify hence would not be identified to any sibling species. The bands obtained are as shown in Fig. 5.
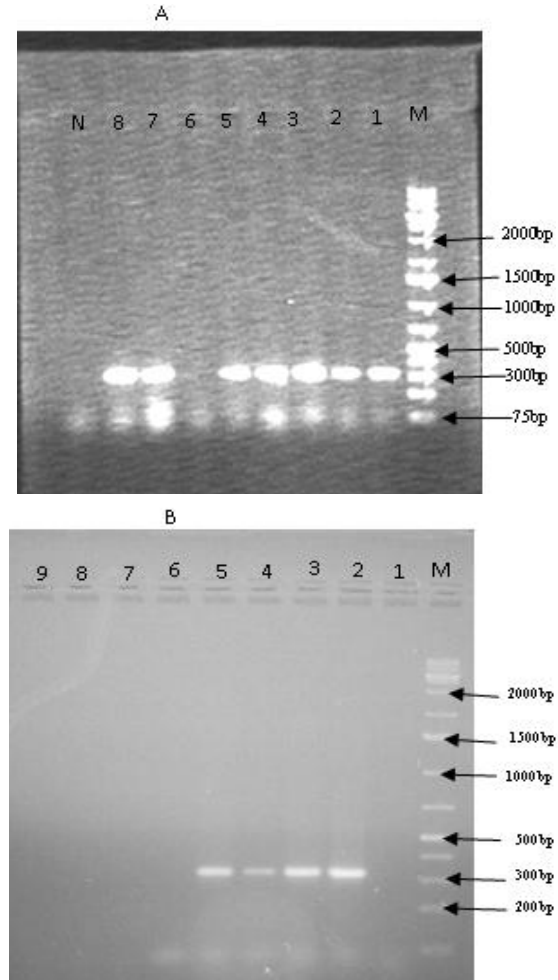

Fig. 5: Electrophoresis gels showing the position/size of band obtained. A and $\mathrm{B}$ are gels, $\mathrm{M}$ is the separation of molecular marker, $\mathrm{N}$ is the negative control and the numbers 1-9 indicate the wells.

Anopheles gambiae complex mosquitoes consist of An. quadriannulutus (153bp) A. arabiensis (315bp) A. gambiae (390bp), An. melas (464bp) and An. merus (466bp). Of these, the band sizes which were expected were $315 \mathrm{bp}$ for $A$. arabiensis and 
390bp for A. gambiae. As per figure $5 \mathrm{a}$ and $5 \mathrm{~b}$, the band sizes obtained in this study were $315 \mathrm{bp}$ corresponding to A. arabiensis.

\section{DISCUSSION}

Considering that the susceptible A. gambiae, Kisumu strain mosquitoes were used to test both for knock down and mortality rates, the low mortality rate achieved by Nigerian Baygon ${ }^{\circledR}$ is likely to be an indication of reduced efficacy rather than development of resistance. This is due to fast knock down rates achieved by the insecticides in this study. However, given that pyrethroid insecticidal resistance has been reported previously $[27,28,14]$ insecticide resistance cannot be ruled out. Most of the aerosol insecticides with the exception of Kenyan Raid ${ }^{\circledR}$, Baygon ${ }^{\circledR}$ and Nigerian Baygon ${ }^{\circledR}$ gave fast knock down and high mortality rates of $A$. gambiae mosquitoes. However, the mean indoor resting densities of $A$. gambiae complex mosquitoes did not differ significantly after insecticide spray $(\mathrm{p}>0.05)$. This implies that the spray of insecticides did not significantly deter/suppress the entry of mosquitoes into the houses. Due to some pyrethroid insecticide resistance already reported in some parts of Kenya and the African continent $[29,30]$ this can be a threat to vector control. Some previous study from Western Kenya did not find proof of any pyrethroid resistance [31]. Whether pyrethroid insecticide resistance will have occurred since then up to the time of carrying out this study is unlikely due to the short span of time. However this can be investigated in another study. Looking at the isomers constituting the insecticides will help to determine whether active ingredients affect efficacy. As obtained from the manufacturers' labels the insecticides were constituted as given in Table 1. From the knock down rates Kenyan Raid ${ }^{\circledR}$ and Kenyan Baygon were least effective, and Nigerian Baygon ${ }^{\circledR}$ achieved the lowest mortality rates of $A$. gambiae mosquitoes. The common isomers used to constitute the three insecticides (Kenyan Raid ${ }^{\circledR}$, Kenyan Baygon ${ }^{\circledR}$ and Nigerian Baygon ${ }^{\circledR}$ ) are Imiprothrin and Cyfluthrin. Arguably the combination of imiprothrin and cyfluthrin does not necessarily achieve higher efficacy. It is likely that a substitution of these active ingredients or addition of a third isomer may result to higher efficacy, subject to further investigation. Even though, Baygon ${ }^{\circledR}$ from Nigerian was constituted by the addition of a third active ingredient, this did not translate to higher efficacy in terms of mortality rates of Anopheles gambiae mosquitoes though faster knock down times were realized. Thus addition of more active ingredients does not necessarily translate to higher efficacy. In a study by Pemba and Kadangwe [5] insecticide A with three active ingredients was found to be more effective than insecticide $B$ which was constituted with four active ingredients. Therefore reconstitution of the pyrethroid insecticides with more potent active ingredients or higher concentration might be necessary to enhance their effectiveness. In another study [18] different aerosol insecticides with different active ingredients achieved different mortality rates of Aedes aegypti mosquitoes. With respect to molecular characterization, a hundred per cent of all the successful amplifications of Anopheles gambiae complex mosquitoes corresponded to Anopheles arabiensis sibling species perhaps indicating it to be the main sibling species in Kigoche village of Ahero part of western Kenya. The failure of some samples to amplify can be attributed to the quality of DNA used and the status of mosquito from which DNA was extracted i.e. if the mosquitoes were blood-fed or not. This can also be attributed to optimization of the PCR conditions [32], however since this was done in this study, this can be ruled out as a contributing factor to the amplification failures. Since no any other sibling species apart from Anopheles arabiensis was identified by molecular means, it is unlikely that any of the failed amplifications would identify to any other sibling species. In previous studies from the same region A. arabiensis mosquitoes were found to be the only sibling species of $A$. gambiae complex mosquitoes [33, 34, 31]. In a study carried out at Mwea rice irrigation scheme, A. arabiensis mosquitoes were found to be the only member of $A$. gambiae complex mosquitoes [35]. The abundance of $A$. arabiensis mosquitoes in irrigated rice fields has been attributed to the provision of permanent and extensive aquatic habitats for larvae development [36]. The fact that $100 \%(71 / 107)$ of the identified species corresponded to $A$. arabiensis mosquitoes, is an indication that the species might have developed a way of circumventing the harsh environmental conditions as compared to other sibling species. Ahero being a rice field where there is extensive use of pyrethroids and a scaling up of Insecticidal Residual Sprays (IRS) by the ministry of public health, it is possible that $A$. gambiae sibling species which is more susceptible might have found it hard to survive in the region. A previous study by Muturi et al [36] found a high number of rare alleles in A. arabiensis population, suggesting that the species has a higher potential of responding to environmental changes and pressures imposed by control measures. Perhaps this is why $A$. arabiensis can survive the effect of insecticides used in rice fields as compared to its sibling species of $A$. gambiae s.s. Therefore any vector control strategy against malaria and other vector-borne diseases in Ahero village part of western Kenya needs to focus on A. arabiensis mosquitoes.

\section{CONCLUSION}

The significant difference in knock down rates by the different insecticides in terms of $\mathrm{KT}_{50}$ and $\mathrm{KT}_{95}$ was as a result of Kenyan Raid $^{\circledR}$ and Kenyan Baygon ${ }^{\circledR}$. The mortality rates of $A$. gambiae achieved by most insecticides was $\geq 97 \%$, Nigerian Baygon $^{\circledR}$ achieving the least with $87 \%$ mortality which gives a cause to worry as far as malaria vector control interventions are concerned. Lack of significant differences in suppression of indoor resting density of $A$. gambiae complex mosquitoes into houses in the field suggest a reduced efficacy of the insecticides. Whether this is due to insecticide resistance is unlikely due to previous study. However this can be authenticated in another study. There is need to reconstitute the insecticides with more potent active ingredients to ensure higher efficacy in terms of mortality rates. All the amplified A. gambiae complex mosquitoes from Ahero village part of Western Kenya, Kisumu County 
corresponded to A. arabiensis. Any malaria vector control strategy from the region should target this sibling species.

\section{LIST OF ABBREVIATION}

CEBIB: Centre for Biotechnology and Bioinformatics,

A. gambiae: Anopheles gambiae

A. arabiensis: Anopheles arabiensis

$\mathrm{KT}_{50}$ : Time taken to knock down $50 \%$ of the mosquitoes

$\mathrm{KT}_{95}$ : Time taken to knock down $95 \%$ of the mosquitoes

PMI: President's malaria initiative

95\% CI: Confidence Interval

CDPH: California Department of Public Health

\section{COMPETING INTERESTS}

The authors declare that they have no competing interests

\section{AUTHORS' CONTRIBUTION}

The study was conceived by DOO, VOO and RWM. All the authors participated in the design of the study. NKM conducted all the experiments, analysis of data and drafting of the manuscript. The final version of the manuscript was read and approved by all the authors.

\section{ACKNOWLEDGEMENT}

We thank the University of Nairobi, School of Biological Sciences for allowing us to use insectary for breeding of Anopheles gambiae mosquitoes and conducting laboratory efficacy study. We also thank the Centre for Biotechnology and Bioinformatics, University of Nairobi for allowing us to use their laboratory for molecular characterisation of Anopheles gambiae complex mosquitoes. We acknowledge the principal for Ahero Multi-purpose Development Training Institute (AMDTI) for allowing us to use their facilities during field work.

\section{Financial support and sponsorship: Nil.}

Conflict of Interests: There are no conflicts of interest.

\section{REFERENCES}

1. Global Malaria Report. World Health Organization Geneva. 2012

2. Snow RW, Guerra CA, Noor AM, Myint HY, Hay SI:The global distribution of clinical episodes of Plasmodium falciparum malaria. Nature. 2005; 434:214-217.

3. Longhorne J: Immunology and Immunopathogenesis of Malaria. London NW7 1AA : The Ridgeways, Mill Hill: National Institute for Medical Research. 2005.

4. CDPH: Vector-borne disease section annual report. California Department of Public Health 2011.

5. Pemba D \& Kadangwe C: Mosquito control Aerosol's efficacy based on pyrethroids constituents. Insecticides-Advances in integrated Pest management. 2012; 26:601-612.

6. CDPH: Operational plan for emergency response to mosquito-borne disease. California Department of Public Health 2013
7. Gillies MT \& DeMeillon B: The Anophelinae of Africa south of the Sahara (Ethiopian Zoogeographical Region). Publications of the South African Institute for Medical Research.1968. No. 54.

8. Coetzee M, Hunt RH., Wilkerson R, della torre A, Culibaly MB., Besansky NJ: Anopheles coluzzii and Anopheles amharicus, new members of the Anopheles gambiae complex. Zootaxa 2013; 3619 (3): 246-273.

9. Gillies MT \& Coetzee M: A supplement to the Anophelinae of Africa South of the Sahara (Afrotropical Region). Publications of the South African Institute for Medical Research. 1987p. No. 55.

10. Hunt RH, Coetzee M, Fettene M: The Anopheles gambiae complex: a new species from Ethiopia. Transaction of Royal Society of Tropical Medicine and Hygiene. 1998; 92: 231-235. .

11. Lengeler $C$ :Insecticide-treated bed nets and curtains for preventing malaria. Cochrane Database of Systematic Reviews. 2004 CD000363.

12. WHO: Guidelines for efficacy testing of household insecticide products. World Health Organization Geneva 2009

13. Hargreaves K, Koekemoer LL, Brooke B, Hunt RH, Mthembu J, Coetzee M: Anopheles funestus resistant to pyrethroids insecticides in South Africa. Journal of Med Entomology. 2000;14:181-9.

14. N'Guessan R, Corbet V, Akogbeto M, Rowland M: Reduced efficacy of Insecticide-treated Nets and Indoor Residual Spraying for malaria Control in Pyrethroid resistance area, Beni. Emerging Infectious Diseases. 2007;13(2).

15. Kelly-Hope L, Ranson H, Hemingway J: Lessons from the past: managing insecticide resistance in malaria control and eradication programmes. Lancet Infectious Diseases. 2008, 8:387-398.

16. Matowo J, Kulkarni M A, Mosha FW, Oxborough RM, Kitau JA, Tenu F, Rowland M: Biochemical basis of permethrin resistance in Anopheles arabiensis from Lower Moshi, northeastern, Tanzania. Malaria Journal. 2010; 9:193.

17. Zairi $\mathrm{J}$ \& LeeYW: Laboratory and field evaluation of household insecticide products and public health insecticides against vector mosquitoes and house flies. Malaysia: Perniagaan Ph'ng@P\&Y Design Network. Proceedings of the Fifth International Conference on Urban Pests Malaysia. 2005; 478-482.

18. Khadri MS, Kwok KL, Noor MI, Lee HL: Efficacy of commercial household insecticide aerosol sprays against Aedes aegypti (Linn) under simulated field conditions. Southeast Asian Journal of Tropical Medicine Public Health. 2009; 40(6): 1226-34.

19. Seccacini E, Masuh H, Licastro AS, Zerba NE: Laboratory and scaled up evaluation of cis $า$-permethrin applied as ultra low volume formulation against Aedes aegypti. Acta Tropica. 2005; 97 1-4.

20. WHO: Manua on practical entomology part II. World Health Organization Geneva. 1975.

21. Livak K: Organization and mapping of a sequence on the Drosophila melanogaster $\mathrm{X}$ and $\mathrm{Y}$ chromosomes that is transcribed during spermatogenesis . Genetics. 1984; 107:611-634.

22. Collins FH, Finnerty V, Petrarca V: Ribosomal DNA probes differentiate five cryptic species in the Anopheles gambie complex. Parassitologia. 1988; 30:231-240.

23. Townson H, Harbach R, CallanT : DNA identification of museum specimens of the Anopheles gambiae complex:an eavaluation of PCR as a tool for resolving the formal taxonomy of sibling species complexes. Systematic Entomology. 1999; 24, 95-100.

24. Scott JA, Brogon WG, Collins FH: Identification of single specimen of the Anopheles gambiae complex by polymerase chain reaction. American Journal of Tropical Medicine and Hygiene. 1993; 49: 520529.

25. Wilkins EE, Howell PI, Benedict MQ: IMP PCR primers detect single nucleotide polymorphisms for Anopheles gambiae species identification, Mopti and Savanna rDNA types, and resistance to dieldrin in Anopheles arabiensis. Malaria Journal. 2006; 5:125

26. WHO: Test procedures for insecticide resistance monitoring in malaria vector mosquitoes. World Health Organization Geneva. 2013 
27. Elissa N, Mouchet J, Riviere F, Meunier JY, Yao K: Resistance of Anopheles gambiae s.s. to pyrethroids in Co Te d'Ivoire. Anneles de la Societe. Belge de Medecine Tropicale. 1993; 73: 291-294.

28. Chandre F, Darrier F, Manga L, Akogbeto M, Faye O, Mouchet J: Status of Pyrethroid resistance in Anopheles gambiae sensu lato. Bulletin of WHO. 1999; 77:230-4.

29. Vulule JM, Beach RF, Atieli, Roberts JM, Mount DL, Mwangi RW. Reduced susceptibility of Anopheles gambiae to permethrin associated with the use of permethrin-impregnated bednets and curtains in Kenya. Medical and Veterinary Entomology. 1993; 8:1-75

30. Chen H, Githeko A.K, Githure JI, Mutunga J, Zhou G, Yan G: Monooxygenase Levels and Knockdown Resistance (kdr) Allele Frequencies in Anopheles gambiae and Anopheles arabiensis in Kenya. Journal of Medical. Entomology. 2008; 45(2) 242-250.

31. Kamau L, Agai D, Matoke D, Wachira L, Gikandi G, Vulule JM: Status of insecticide susceptibility in Anopheles gambiae sensu lato and Anopheles funestus mosquitoes from western Kenya. Journal of Insect Science. 2008; 8(11).

32. Rivero J, Erdaneta L, Zoghbi N, Pemalete M, Rubio-palis Y, Herrera F: Optimization of extraction procedure for mosquito DNA suitable for PCR-based techniques. International Journal of Tropical Insect Science. 2004; 24(3) 266-269.

33. Zahar AR: Vector bionomics in the epidemiology and control of malaria. Part 1. TheWHOAfrican Region and the southern WHO Eastern Mediterranean Region. Geneva: World Health Organization mimeographed documents. 1985; VBC/85.3.

34. Stump AD, Atieli FK, Vulule JM, Besansky NJ: Dynamics of the pyrethroids knockdown resistance allele in western Kenyan populations of A. gambiae in response to insecticide-treated bed net trials. American Journal of medicine and Hygiene. 2004; 70(6 ) 591 596.
35. Vulule MJ \&Kamau L: Status of insecticide susceptibility in Anopheles arabiensis from mwea rice irrigation scheme, central Kenya. Malaria Journal. 2006; 5:46.

36. Muturi JM, Kim HC, Baliraine NF, Musami S, Jacob B, Githure J, Novak JR: Population genetic structure of Anopheles arabiensis (Diptera:Culicidae) in a rice growing area of central Kenya. Journal of Med Entomology. 2010; 47(2)144-151.

\section{How to cite this article:}

Makworo NK, Ochieng VO, Ogoyi DO, Mukabana RW. Knock down efficacy of commercially available insecticides against Anopheles gambiae. J App Biol Biotech. 2017; 5 (02): 077-084. 